\title{
Jar Dosing Unit
}

National Cancer Institute

\section{Source}

National Cancer Institute. Jar Dosing Unit. NCI Thesaurus. Code C48502.

A dosing unit equal to the amount of active ing redient(s) contained in a jar. 